\title{
The Effect of Tourism Development on Land Conversion in East Lombok Regency
}

\author{
Anisa Yudita \\ Graduate Student of Geography Education, Faculty of Social Science,Universitas Negeri Padang. \\ Email: anisayudita@gmail.com
}

\begin{abstract}
Tourism is one of promising aspects which is growing rapidly today. Indoensia is the fourth tourism destination in South East Asia. The data from Government Tourism Office found that there has been an increasing number of visitors to Indonesia in the last three years. This certainly requires the development of supporting aspects, such as roads, transportation, facilities, accommodation and some other supporting aspects of tourismobjects. This research was aimed to know the effect of tourism development on land conversion in the coastal area of East Lombok Regency. This study employed a mixed method research (qualitative and quantitative). The reason of using this research method was to obtain the information that meet this research's purposes. This research cllected primary and secondary data which were related to tourism and lad conversion. The data was obtained from field observation, interview, literature review, documentation, image analysis and additional information from related agencies. The result of this research revealed very slow development of tourism objects in coastal area of East Lombok Regency. Consequently, it resulted on very few land conversion in the coastal area of East Lombok due to a slow tourism development.
\end{abstract}

Keywords :Tourism, Tourism Development, Land Conversion, Coastal area, East Lombok

\section{Introduction}

Tourism sector is one of idustry and service sectors which is rapildly growing and very promising. As an archipelagic country, has a unique geographical conditions. Indonesia has the third longest coastal line in the world and is a country which is passed by The Ring of Fire. This condition makes Indonesia become an attractive tourism destination. So, lately, many unexplored places turn into tourism destination that attract local, regional or international visitors. One of them is tourism in East Lombok Regency, West Nusatenggara Province. Based on the constitution number 10 year 2009 about tourism. It is stated that the natural condition,flora dan fauna given by God almighty one, ancient and historical relics, and art and culture owned by Indonesian are tourism resources and development assets to improve welfare and proerity of the people as menitoned in Pansila and in the opening of Indonesia's 1945 Constitutions. In other words, Indonesia agreed that tourism is one of sectors to improve Indonesian' welfare and properity.

Kanom (2015) stated that tourism in Lombok generally is not yet develoed compared to tourism in Bali which is Indonesia' tourism barometer. Tourism development in Lombok is necessary as an effort to support national tourism development since Lombok is one of National Tourism Destination (DPN) for example Lombok-Gili Tramena and its surrounding, In addtion, in Government Regulation number 50 yeaer 2011 regarding master plan for national tourism development said that tourism is one of sectors which aims to improve Indonesian's wefare aand properity. Ander and friends (2016) stated that the potential of Lombok is its natural potential including sunrise and sunset viewing, the beauty of the beach, and its sea and hills which is arranged like a green border fortress. Then,there is its cultural potential including community culture such as traditional ceremony of Sasak, traditional crafts and arts, tradition of bau nyalel and presean.

Utomo (1992) in Handoko Probo Setiawan (2016) definedland conversion as functional changes of a part or all of the land from its original function(as planned) to other function which negatively affect the environment of the land and its potential. Land conversion, in term of changes/adjustments in use, is caused by factors that are generally related to the necessity of meeting the needs of a growing society and increasing 
demands for better life. Catur TB and friends (2010)mentioned in their research that an increasing standard of living and the opening opportunities to create job vacancy which is shown by the number of investors, society and government who conduct the development, is in line with an increasing need for the land. Increased demand for land is driven by an increase in population despite the availability of the land and its fixed area. This results in reallocating the land use from less provitable activities to more provitable ones. This activity mostly threatens agricultural activity which is considered less profitable compared to other economic activities.

Basically, land conversion certainly will have an impact on existing balance.as mentioned by Dedi Hermon that, the conversion of forest, agricultural land, and bush for the sake of economic improvement leads to an icrease GHG concentration improvement. An increase in green house gas cocentration will directly affect on global warming and climate change. Glenn Kreag stated that the impact will be in manifested in economic impact, socio-cultural impact and environmental impact.He added that not only negative impact, but land conversion can also have positive impact. There are 13 coastal tourism objects in East Lombok. Other than coastal tourism, East lombok also presents mountain tourism destination for example Rinjani moutain, a second highest eruptive mountain in Indonesia, cultural tourism, and other various tourism destinations (Armin Subhani, 2010).Agricultural products are potential to be processed into local food which will support the development of local tourism. Now, there are some local food to be realized in some areas in Lombok Island (Zainuri).Tourism is an industrial and service sector that relies on services, including nonphysical service such as hospitality of local people and physical services such as adequate infrastructure, transportation and accomodation (airport,ship, bus, taxibike, road access and others), inn, accessibility, and basic things like security procedure,eligible oxygen tube for diving, and swimming vest for shipping and others.

The procurement of tourism supporting facilities needs land for building. The facilties as airport, inn, restaurant, and other things are for tourists' comforts. by doing so,it is hope that many visitors will come to East Lombok. The development use lands which were used to be a agricultural land, field, rice fields, coastal area or local people's business location. Agus Dipayanaa dan I Nyoman Sunarta (2015)said that facilities such as villa, hotel, and guest house are rapidly growing following the development of tourism. Rapid growth of accomodation facilities proves that the majority of these accomodation facilites are constructed in former agricultural lands. The land conversion have a big impact on the local community especially on their social culture whether the effect is tangible or intangible. According to Handoko Probo Setiawan (2016), generally, the owners of converted land are the old people who need to improve their economic condition. Moreover, enviromental factors could also affect the decision to convert the land. Other than daily expenses, the owners also need to spend their money on workers to cultivate the land. Therefore, they sold the land to reduce financial burden. In addition, Kustiawan (1997) in Ida and Made (2015) explained that land conversion is also affected by external and internal factors and government policy. External factors include spatial, demographic and economic growth of urban area which encourage land conversion. Internal factor is related to socio-economic conditions of a familiy that force them to sell the land. Based on those phenomenda, the researcher were interested to do further research on the effect of tourism development on land conversion in East Lombok regency.

\section{Method}

This study was conducted in East Lombok Regency, one of regencies in West Nusa Tenggara Province. The focus of this researchis the effect of tourism development on land conversion in that area. This research is mixed method research. The researcher used both qualitative and quantitative research method in order ensure the relevance between the data collected from the field and the data from the local people. Two types of data, primary and sencondary data, was collected. Primary data was collected by doing interviews 
and observation in the field. Meanwhile,secondary data was obtained from literature reviews and from related agencies that would support the research. the techniques of data collection were direct observation in the field, open-ended interviews with selected informants, literature review and documentation study. To select the informant, the researcher conducted purposive sampling technique. This means, the informants were not meant for representing population but for representing information. Furthermore, collected data was analyzed and described based on the purpose of the research. Next, the researcher conducted image analysis to know how large the land being converted due to tourism development in coastal area in East Lombok Regency. Image analysis was done in order to integrate the spatial data into one unit data. As stated by Sayfiah (2017), GIS (Geography Information System)is used to provide the resource managers and policy makers with a mean to monitor eco-tourism development andtarget achievement of sea conservation. GIS can be implemented to integrate informations in order to explore the interaction between human activities and marine resources. The Spreading of cummulative effect is beneficial for developing spatial management scenario to identify hotspot area of human activites and threats and important areas for conservation. Moreover, the implementation of GIS (in this case for integrating information, summary, and visualization) was proved to be beneficial because it could perform spatial based analysis on ecosystem level and could be presented in a way that will improve the understanding of the stakeholdersis about obtained informationfor the sake of supporting government interaction. Therefore, the researcher also used GIS analysis in order to achieve this research purpose.

\section{Result and Discussion}

\section{The Condition of Coastal Tourism in East Lombok}

As one of Indonesia's top tourism destinations, Lombok Island not only presents its cultural tourism but also its natural tourism. Other than the existence of Rinjani Mountain, Lombok is also welknown by the visitors for its coastal landscape. Lombok has same characteristic as other islands in Indonesia. Little amount of rainfall makes East lombok to have grassed hills which are looked like a savannah and meadow with few growing trees in it. The condition of coastal area in Lombok Island was well preserved and there had not been many polution in coastal area in East Lombok. Its natural condition was also well preserved and there were no many visitors. The number of visitors that come to a trourism destination is affected by 4 aspect, as mentioned by Cooper:

\section{Atraction}

Attraction is all the interesting things that can be enjoyed by the visitors in a tourism destinations. Tourism attraction could be in form of natural scenary, gamesor traditional and cultural performance such as dances, cultural attraction, and cultural ceremony or celebration. Coastal area in East Lombok has beautiful natural landscape with no additional attraction like arts, game, and others. Its limited attraction discourage people to visit the area because natural scenary can be enjoyed in all part of Lombok not only in East Lombok.

Accessibility

Accessibility is related to facilities and infrastructure to access the tourism destination, including road access, the availability of transportation, and traffic signs to direct visitors to the destination. From several beaches in coastal areas visited by the researcher, a major concern of accessibility was the condition of the road to tourism location. To reach coastal areas of East Lombok, the visitors must travel a long distance from the residential area and to make it worse, the road has not been paved or full of rocks and dust but still passable for cars and motorbikes. On several occasion, there were some bikers who were stucked in the road or looking for a ride due to flat tires. Another limited accessibility was the lack of transportations to the tourism destination because the location could only be accessed by private vehicles or by rented vehicles. 
This becomes the main obtacles of the tourism, because no matter how good the tourism attractions are, if the location is difficult to be accessed, they visitors have to think twice to visit the location.

Amenitas

Amenitas is related to the things that support activities in tourism location for example, inns or hotels, toilets, parking lots, restaurants, and available worship place. These things were hardly found in coastal area of East Lombok. In several location, there were some stalls owned by local people but they were not managed professionally because the people trade on their own initiatives. There were also very little hotels, inns and other facilities, even in some location there were no inns or worship place available to the place is convenient only for momentary visits not for overnight visits.

Ancilliary

Ancilliary is concerning the existence of an organization or a group of people who take care of and manage a destination to be a worthy tourism attraction to visit. The organization who manage and run the place could be from private organization, government, or local people who are trusted to manage the tourism destination. By doing so, the accessibility, amenitas, and attraction could be optimally managed.

There are may Beach destination that could be visited in East Lombok. They are:

1. Pink Beach

2. Tangsi Beach

3. Kura-Kura Beach

4. Ekas Beach

5. Cemara Beach

6. Ringgit Beach

7. Penyisok Beach

8. Batu Dagong Beach

\section{The Effect of Tourism Development on Land Conversion in East Lombok Regency}

Coastal tourism development in East Lombok is very different from the tourism development in other coastal areas in lombok, especially compared to West Lombok. Actually, it was also affected by the distance between the location and city centerand economic centre, Mataram City. Moreover, 5 to 6 hours distance between airport and the tourism destination is the cause of little number of visitors in coastal tourism in East Lombok. The lack of visitors discourage investors to invest in this area eventhough East Lombok coastal area is as beutiful, exotic, and fascinating as other coastal areas in Lombok. The lack of accessibility, bad road access and lack of inns become the major problems both for the tourism objects and the visitors. Following figures are the maps produce through image processing of East Lombok Regency in 2007 and 2012 regarding land use in coastal areas of East Lombok regency: 

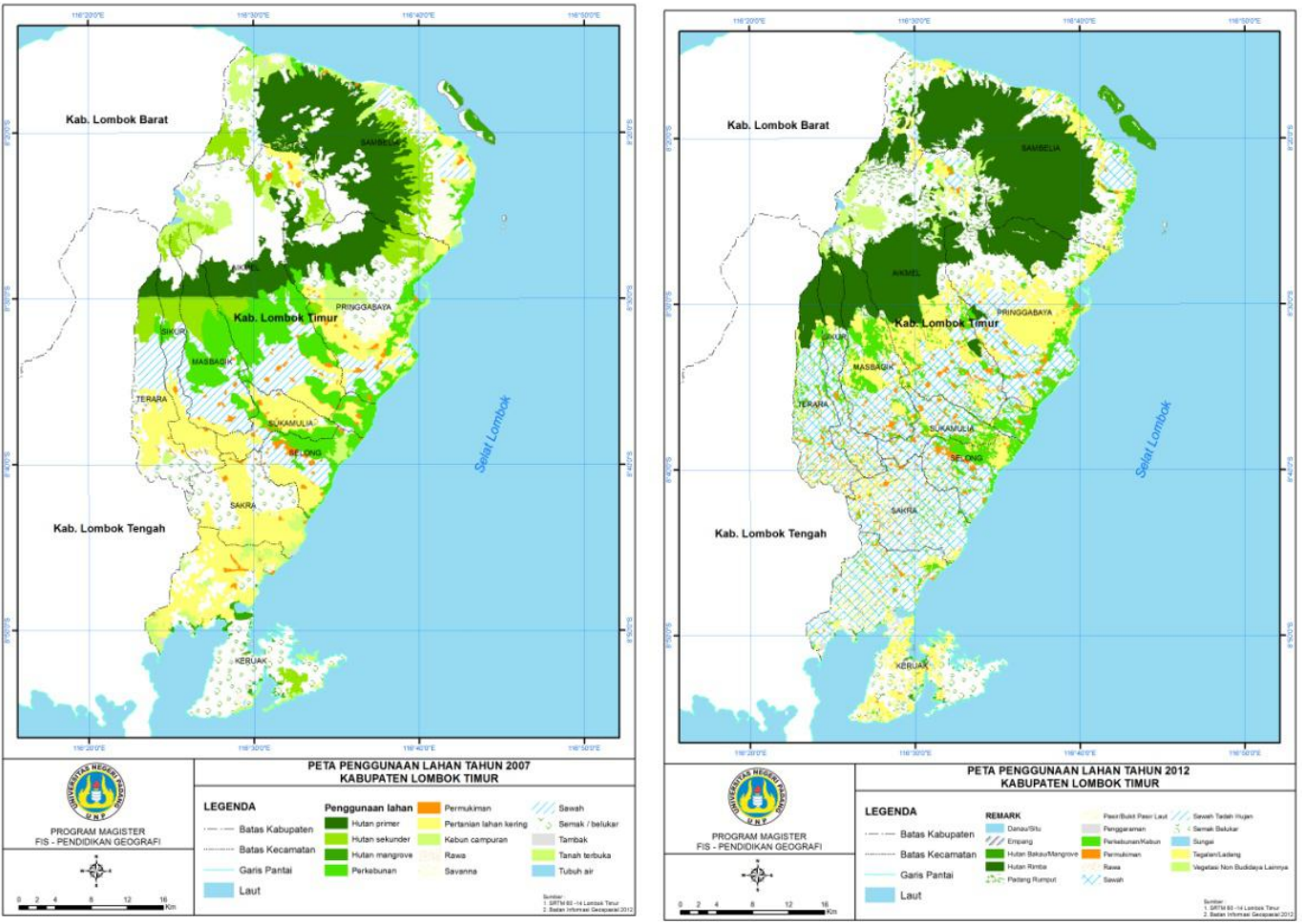

Figure 1. Map of Land Use in 2007 and 2012

Based on the Figure 1, there were a significant land changes in East Lombok. The lands which were used to be used for dryland farming were converted to rice fields. Regarding land conversion on coastal area, there were no significant changes of the land due to insignificant tourism development in coastal area in East Lombok.

This opened land cover is very suitable for beach tourism or recreation. The majority of coastal tourism areas in Padang have buildings that have been equipped with rinse spot and toilets (supporting tourism) and every unit was equipped with rinse-water and special bathrooms and have easy access to the location (Aprizon dan Tri, 2017)

Te principles of coastal tourism management should adopt low enviromental risk principles as proposed by Victor PH Nikijuluw (2017). Low enviromental risk principles sould be applied for the radical and subtantial economic develoment because it will change the structure and function of coastal area. The development can not be dismissed but it can be manage as wise as possible so that the structure and function of coastal ecosystem will not change. The latest cutting-edge technology can be used to simulataneously maintain the structure and function of the ecosystem. Destructive practices such as coastal reclamation for are not a smart solution to having more space and gaining more land for so-called development goals. Additional space for urban development can be ontained without changing the contour and structure of coastal area. In other words, coastal area management needs a careful planning and policy and should not rely on human ego alone.

Limited access, facilities, infrastructureo, suppoting toursim facilities and the lack of realization from the authorities (government) result in a slow development of coastal area in East Lombok. The slow development of coastal tourism also insignificantly convert the land. In several tourism destination, homoheneous molted forest can still be found and in pink Beach, there is bushy and dense plant around the road access. Then, along the road there found beautiful savannah hills which are untouched (by the 
development). Even after arriving in coastal tourism area, a beautiful and original forest is still existed as if it is never touched by human's hands. Finally, it can concluded that there is no a significant, or disturbing, land conversion in the coastal area of East Lombok.

\section{Conclusion}

The result of this research showed a rapid development of tourism destination in Lombok Island and this means an opportunity for investors. However, a significant development could not be found in coastal area in Lombok Island.The goverment should pas special attention in developing tourism destination in coastal area of East Lombok especially in developing accessibilites of the destination, supporting tourism facilities and its management. Insignificant development of coastal area in Lombok Island resulted in insigficant land conversion especially in coastal area of East Lombok Regency.

\section{References}

Anonim. (2009). Undang - Undang RI Nomor 10 Tahun 2009 tentang Kepariwisataan.

Agus dan Nyoman. (2015). Dampak Pariwisata Terhadap Alih Fungsi Lahan Di Desa Tibubeneng Kecamatan Kuta Utara Kabupaten Badung (Studi Sosial-Budaya). Jurnal. Prodi Pariwisata Universitas Udayana Bali.

Ander, dkk. (2016). Strategi Pengembangan Kuta Lombok sebagai Destinasi Pariwisata. Jurnal. IPTA.

Catur, dkk. 2010. Dampak Alih Fungsi Lahan Pertanian ke Sektor Non Pertanian Terhadap Ketersediaan Bebas di Kabupaten Klaten Propinsi Jawa Tengah. Jurnal. Caraka Tani.

Hermon, D. (2014). “Impacts of Land Cover Change on Climate Trend in Padang Indonesia”. J. International Journal Geography. UGM. Yogyakarta

Ida dan Made. (2015). Faktor-Faktor Pendorong Alih Fungsi Lahan Sawah Menjadi Lahan Non-Pertanian. Jurnal. Program Studi Agribisnis Fakultas Pertanian Unversitas Udayana Bali.

Kanom. (2015). Strategi Pengembangan Kuta Lombok sebagai Destinasi Pariwisata Berkelanjutan. Jurnal. Jurnal Master Pariwisata.

Kreag, Glenn. (2013). “The Impact of Tourism”. Sea Grant Minnesota, Publication number: T13

Nikijuluw, Victor PH. (2017). Coastal Resources Conservation in Indonesia:Issues, Policies, and Future Directions. Sumatra Journal of Disaster, Geography and Geography Education ISSN: 2580-4030 (Print) 2580-1775 Vol 1, No. 1, (pp. 15-23)

Putra, dkk. (2017). "The Suitability Ecotourism Beach Based Geopasial in Padang City, Indonesia (CaseStudy of Category Recreation Beach and Mangrove)". Padang. Sumatera Journal of Disaster, Geography and Geography Education ISSN:2580-4030Vol1,No.1,(83-91).

Setiawan, Handoko Prabowo. (2016). Alih Fungsi (Konversi) Lahan Pertanian ke Non Pertanian Kasus di Kelurahan Simpang Pasir Kecamatan Palaran Kota Samarinda. Jurnal. E-Journal Sosiatri-Sosiologi.

Subhani, Armin. (2010). Potensi Objek Wisata Pantai di Kabupaten Lombok Timur Tahun 2010. Tesis. Program Studi Pendidikan Kependudukan dan Lingkungan Hidup Universitas Sebelas Maret Surakarta.

Yusmah, Safiah. (2017). Geospatial Based Coastal Ecotourism Management for Geography Teaching Material Development. Sumatra Journal of Disaster, Geography and Geography Education ISSN: 2580-4030 (Print) 2580-1775 Vol 1, No. 1, (pp. 1-6)

Zainuri, dkk. (2016). Keragaman Pangan Lokal di Pulau Lombok Untuk Menunjang Pengembangan Pariwisata. Jurnal. Fakultas Teknologi Pangan dan Agroindustri Universitas Mataram. 